\title{
Implementation Of Integration Learning Model In Universitas Negeri Medan
}

\author{
Rosnelli $^{1 *}$, Sarwa ${ }^{2}$,Fahmy Fyahputra ${ }^{3}$ \\ ${ }^{1,2,3}$ Faculty of Engineering, Universitas Negeri Medan, Indonesia \\ *rosejitu62@gmail.com
}

\begin{abstract}
This study aims to implement an integrated learning model in an effort to improve student learning outcomes in the Industrial Engineering course at the Faculty of Engineering Unimed. Another research objective is to determine the impact of implementing the integration learning model. The research method used was quasiexperimental. Data collection through a questionnaire to capture the learning impact and the accompanying impact of the integration model implementation. To see the learning outcomes used tests. To see the conditions of higher learning outcomes used the test. The results showed that the learning outcomes of students using the integration learning model were higher when compared to student learning outcomes using an expository learning model in which they conducted experiments in the workshop. The impact of the implementation of the integrated learning model is that there is an increase in learning outcomes, besides the accompanying impact is the growth of creativity, selfdetermination, student motivation in producing innovative products based on the specifications of the study program chosen.
\end{abstract}

Keywords: Implementation of Integration learning Model.

\section{Introduction}

Industrial Engineering is a subject at the Fakultas Teknik Universitas Negeri Medan. The integration learning model was developed with the aim of improving the learning outcomes of Industrial Engineering courses [1]. The effectiveness of the integration learning model can be seen through quasi-experimental research by comparing it with expository learning models in which practice is carried out in the workshop.

Industrial Engineering Learning in the Fakultas Teknik facilitates students to produce products that are characteristic of the Fakultas Teknik that are tailored to the talents, interests and specifications of the study program. The results of the course products will be exhibited at expo activities at the Faculty at the end of each semester. The products produced by students are mini research tasks, engineering ideas and projects in learning Industrial Engineering.

\section{Implementation of the Integration Learning Model.}

Implementation of the integration learning model in learning consists of 7 stages. The stages of the integration learning model are: 1) the orientation phase, 2) the self-learning stage, 3 ) the web-based learning stage, 4) the workshops-based learning stage, 5) the percentage of product results, 6) the product results revision stage and 7) the product exhibition stage [1]. The orientation phase is a discussion of learning objectives, learning mechanisms, providing motivation to students and an explanation of the use of the web as a source of learning. 
The independent learning stage, students are facilitated so that they can learn to stand in search for ideas and concepts about the product to be developed, students conduct field studies in an effort to see the comparison of products to be developed with existing products in the field. In this condition students will empower themselves and carry out activities that can trigger their creativity in making decisions about the products to be developed. Before making a decision about the product to be developed, students make instruments about the feasibility of the product they will make.

On the web-based learning stage, students will look for material about products that will be developed through the web. Through web-based learning students will be motivated in product development, in addition it will form a strong self-determination in an effort to increase self-confidence, that they will be able to realize the product development plan. Through web-based learning students will be motivated to make products by looking at products in the field through the web. Students will be able to provide a comparison with the product plan to be developed, so they can express the advantages of the product being developed when compared to those in the field.

The workshop-based learning phase will train students to produce products based on miniresearch in the field. Based on miniresearch students do an idea idea about the product to be developed. Furthermore, students will develop products in the workshop, by consulting the supervisor and expert staff. Work on the workshop will be monitored by supervisors and expert staff so that the products made have a predetermined quality standard.

The product percentage stage is an activity carried out in the classroom in an effort to present the product as well as to show the product being developed by the supervisor and classmates. In the product presentation stage, students will get input in an effort to improve the product being developed. Students will engage in interactive talks with lecturers, expert staff and classmates. From the results of the percentage of students will provide conclusions about the products that will be developed by explaining the parts that will be refined based on input from the supervisor, expert staff and classmates.

The product revision stage was carried out at the workshop. The product revision stage may also be carried out independently, according to the needs of the product revision being developed. the product revision stage is carried out independently, still in consultation with the supervisor and expert staff in an effort to perfect the product being developed. After completing the revision stage, it means that the product developed has been perfect. When the product is in perfect condition, the product is worth showing it to the public.

The product exhibition stage is an activity to showcase all student products in Industrial Engineering learning. In the product exhibition activities students are trained to make product exhibition proposals for stakeholders in an effort to find support for the implementation of a product exhibition. At the product exhibition students design a product exhibition that has been developed, so that it can perform well, is attractive and can provide benefits to stakeholders. In addition, the products on display were in accordance with the talents, interests and specifications of the study programs chosen by students.

The implementation of the integration learning model at the poroduk design plan stage begins with product survey activities in the field in accordance with the interests and areas of expertise. The results of the field survey were analyzed to get the product to be developed primarily about the product name, product usability, product advantages, and product weaknesses. To produce products requires the approval of a lecturer or expert staff about plans to develop product ideas engineered. Analysis of product planning based on market analysis and the results of product surveys in the field. The superior product developed is the result of field survey analysis. 
Identification of the equipment needed in producing the results of engineering ideas starts from product planning in accordance with the interests and areas of expertise, reasons for product selection, product use and identification of the needs of tools and materials to produce products. what is needed and produce product engineering ideas, design the product manufacturing process, the development of the production design process, the development of the production design process requires validation from experts.

\section{Impact of Implementation of Integration Learning Model.}

Implementation of the integration learning model, when students do miniresearch is done in teams. Colquit [2] states that teamwork that supports one another will be able to improve work results. Student work through mini research is field data to determine the products to be made. Based on the analysis of field data students will be able to come up with creative ideas in an effort to determine the product to be made. Through discussions with fellow teams, will be able to come up with creative ideas that can contribute to the excellence of the product to be made when compared to the conditions in the field. This shows that the implementation of the integration learning model can lead to students' creative ideas in creating products. Dwi [3] explains that when a person has high creativity, he will be able to solve the problems he faces. Happy [4] explains that when a person has high self-confidence it will lead to high creativity in solving problems.

The learning process in the workshop activities in realizing the products developed is also a team work. Effective teamwork can increase teamwork productivity [5]. With the increased productivity of teamwork, it will increase student confidence in realizing products that will be developed. When students have high motivation to create products, students will be able to maximize their potential by creating products that will be made. If students already have high self-determination in realizing products, students will see that there is always a solution to the problems encountered in making products that have been planned. High selfdetermination will be able to maximize individual efforts in realizing the goals that have been set in his mind [6]. High self-determination will be able to maximize the efforts made by students to realize the products to be developed.

Implementation of the integration learning model in integration courses requires visionary educators. Endah [7] explained that overall visionary leadership and lecturer performance had a positive and significant effect on university quality. Visionary leadership is able to apply its role as a direction maker, change agent, spokesperson, and trainer. Visionary lecturers who facilitate students in learning integration will be able to motivate students to create innovative products and facilitate students and train students so they can be skilled in realizing developed products. Besides that good management in the learning process, increasing student motivation to produce high performance [8].

Visionary educators can motivate students, especially if facilitated with laboratory equipment and personnel in accordance with the competencies that will be achieved it will be able to motivate students to maximize their potential so as to produce high learning outcomes. Kreitner [9] explains that if individuals in carrying out their work have gained inspiration and motivation, then the individual will be able to improve their work. The work of the individual increases because the individual can increase his potential so as to achieve goals become easy.

Students who are highly motivated will be eager to complete their task of creating innovative products of engineering ideas into real objects that are ready to be exhibited at the expo. As explained by Kiki [10] explains that when someone has a high work motivation, it will be able to produce high performance. 


\section{Research Method}

The study was conducted at the Fakultas Teknik Universitas Negeri Medan. a quasiexperimental research method and to see the high learning outcomes of the two implemented models used a one-party $t$ test. To see the learning outcomes used tests. To find out the effects of learning, questionnaires were used. The study population is lecturers and students who carry out learning in industrial engineering courses. Sampling was done randomly.

\section{Results and Discussion}

Student learning outcomes in the Industrial Engineering course using the integration learning model, showed that there were $36 \%$ of students in the high category. $58 \%$ of students are in the high enough category. $6 \%$ of students are in the low category as in the following table.

Table 1. Student Learning Outcomes Using the Integration Model

\begin{tabular}{cccc} 
Score & f - Observation & f - Relatively (\%) & Category \\
\hline $96-124$ & 0 & 0,00 & Very High \\
$77-95$ & 18 & 36,00 & High \\
$67-76$ & 30 & 58,00 & High Enough \\
$48-66$ & 3 & 6,00 & Low \\
$29-47$ & 0 & 0,00 & Very Low \\
\hline Total & $\mathbf{5 1}$ & $\mathbf{1 0 0 , 0 0}$ & \\
\hline
\end{tabular}

The control class carries out conventional learning which applies an expository learning model in which there is learning in the workshop. The results of the study after being tested by t-test, showed that there were significant differences between the two learning outcomes. Student learning outcomes in learning integration are higher than student learning outcomes in conventional learning. The conventional learning model is learning that uses expository methods which also carry out practical work in the workshop. Learning outcomes with conventional learning models are as in the following table 2. 
Table 2. Learning Outcomes in Conventional Learning

\begin{tabular}{cccc}
\hline Score & f - Observation & f - Relatively $\mathbf{( \% )}$ & Category \\
\hline $91-118$ & 0 & 0,00 & Very High \\
$82-90$ & 4 & 8,00 & High \\
$64-81$ & 41 & 80,00 & High Enough \\
$46-63$ & 6 & 12,00 & Low \\
$28-45$ & 0 & 0,00 & Very Low \\
\hline Total & $\mathbf{5 1}$ & $\mathbf{1 0 0 , 0 0}$ & \\
\hline
\end{tabular}

Table 2. Shows that there are $8 \%$ of students in the high category. $80 \%$ of students are in the high enough category and there are still $12 \%$ of students in the low category. The results of the questionnaire analysis of student creativity that appears in the implementation of the learning integration model are as follows.

Table 3. Condition of Student Creativity in Producing Products.

\begin{tabular}{cccc}
\hline Score & f-Observation & f - Relatively (\%) & Category \\
\hline $106-125$ & 0 & 0,00 & Very High \\
$86-105$ & 25 & 49,00 & High \\
$66-85$ & 23 & 45,00 & High Enough \\
$46-65$ & 3 & 6,00 & Low \\
$26-45$ & 0 & 0,00 & Very Low \\
\hline Total & $\mathbf{5 1}$ & $\mathbf{1 0 0 , 0 0}$ & \\
\hline
\end{tabular}

Table 3 shows that the creativity of students in the effort to produce products developed in the high category. High student creativity can be seen from the results of the products on display that have a variety of superior products, and are suitable to be marketed and in accordance with the talents, interests and specifications of the study program chosen. In addition, students' self-determination also increases as in the following table.

Table 4. Student's Self Determination on Integration Learning Implementation.

\begin{tabular}{cccc}
\hline Score & f - Observation & f - Relatively (\%) & Category \\
\hline $41-71$ & 0 & 0,00 & Very High \\
$72-102$ & 43 & 84,00 & High \\
$103-133$ & 8 & 16,00 & High Enough \\
$134-164$ & 0 & 0,00 & Low \\
$165-195$ & 0 & 0,00 & Very Low \\
\hline Total & 51 & 100,00 & \\
\hline
\end{tabular}

Table 4 shows that students' self-determination to produce mini research, idea engineering and project products in the high category. It is seen that all design plans, can be pursued and realized into superior products that are in accordance with the talents, interests 
and specifications of student study programs. Regarding student motivation in the implementation of learning integration can be seen in the following table.

Table 5. Student Motivation on Implementation of Learning Integration

\begin{tabular}{cccc}
\hline Score & f-Observation & f - Relatively (\%) & Category \\
\hline $107-126$ & 0 & 0,00 & Very High \\
$87-106$ & 31 & 60,78 & High \\
$67-86$ & 20 & 39,22 & High Enough \\
$47-66$ & 0 & 0,00 & Low \\
$27-46$ & 0 & 0,00 & Very Low \\
\hline Total & 51 & 100,00 & \\
\hline
\end{tabular}

Table 5 shows that the motivation of students in learning integration in the category is quite high. This was shown by students when carrying out the production and exhibition process. In the process of product production, exhibition preparation and exhibition, students are still willing to carry out their tasks even though the time has exceeded the schedule. In addition, during the exhibition preparation, all students came up with creative and innovative ideas and high spirits, so that the exhibition was successful.

\section{Discussion}

The results of the analysis test on the research hypothesis, using the t-test, showed that there were significant differences between learning outcomes, between students who used the integration learning model and the conventional learning model. The results of one-party t-test analysis show that the learning outcomes of students who use the integration learning model are higher when compared to the learning outcomes of students who use conventional learning models.

Implementation of the integration learning model, when students are at the stage of the field survey to look for comparisons of product designs to be made, students are motivated to design products that are developed have advantages over products in the field. By looking at products in the field and compared to searching on the web will be able to increase students' self-determination, that they will be able to develop products that have been designed. This self-determination will also be higher when the necessary materials and tools are found in the field. At the time of finishing the product in the workshop, students can come up with creative and innovative ideas in the effort to improve the product. Students' cretivity increases when they get support from lecturers and experts in the effort to create products that are developed.

\section{Conclusions}

Conclusions from the results of the study indicate that student learning outcomes using the integration learning model are higher when compared to student learning outcomes using conventional learning models. The learning impact of the research results shows that students have higher learning outcomes. There is an increase in learning outcomes using the integration learning model. While the other accompanying impact is that it can further enhance creativity, 
self-determination and motivation of students in efforts to create products of mini research, engineering ideas and projects in Industrial Engineering courses at the Faculty of Engineering, State University of Medan.

\section{References}

[1] Rosnelli, Sarwa dan Fahmy Syahputra. Development Of Integration Learning Models In Industrial Engineering Courses In Fakultas Teknik Universitas Negeri Medan. Medan: International Seminar ACEIVE3 (2019).

[2] Colquitt.J.A., Jeffery A Lipine, Michael J Wesson. Organizational Behavior, Improving Performance and Commitment in the Workplace, NY: McGraw-Hill (2009).

[3] Dwi Sambada. Peranan Kreativitas Siswa Terhadap Kemampuan Memecahkan Masalah Fisika Dalam Pembelajaran Kontekstual. Surabaya: Journal pendidikan Fisika dan Aplikasinya (JPFA), No 2, Vol 2. Journal.unesa.ac.id/index.php/jpfa (2012).

[4] Hapy Hapsari Kisti dan Nur Ainy Fardana N. Hubungan antar Self Efficacy dengan Kreativitas pada Siswa SMK. Surabaya: Jurnal psikologi Klinis dan Kesehatan Mental, Vol.1 No. 02 (2012).

[5] Slocum dan Herigel. Principlees of Organizational Behavior (2009).

[6] Rosnelli. Pengaruh Tekad Diri, Peruasi Verbal dan Kesadaran Moral Terhadap Kinerja Adaptif kepala Sekolah Kota Medan. Medan: Pascasarjana Univeritas Negeri Medan (2016)

[7] Endah Christianingsih. Manajemen mutu perguruan tinggi (Studi tentang kepemimpinan visioner dan kinerja dosen terhadap mutu perguruan tinggi swasta di kota bandung. Journal manajemen dan sistem informasi. Vol 9, No 18, (2011).

[8] Veitzal dan Selviana. Education Management. Jakarta: Rajawali Pers. (2009).

[9] Kreitner Robert\& Kinicki Angelo. Orgnizational Behavior. Mc Graw-Hill International (2007).

[10] Kiki Cahaya Setiawan. Pengaruh Motivasi Kerja terhdap Kinerja Karyawan Level Pelaksana di devisi Operasi PT. Pusri Palembang, Jurnal Psikologi Islami Vol. 1 No. 2 43-53 (2015) 